\title{
Isolation and identification of Treponema pedis and Treponema phagedenis-like organisms from bovine digital dermatitis lesions found in dairy cattle in Turkey
}

\author{
I. Demirkan, ${ }^{\star 1}$ M. Erdoğan,† A. Çevik Demirkan,‡ F. Bozkurt,§ M. Altındiş,\# F. Zemheri Navruz,II and Z. Köseđ \\ *Department of Surgery, \\ †Department of Medical Biology and Genetics, \\ $\ddagger$ Department of Anatomy, and \\ §Department of Pathology, Faculty of Veterinary Medicine, Afyon Kocatepe University, Afyon, 03200, Turkey \\ \#Department of Clinical Virology and Microbiology, School of Medicine, Sakarya University, Sakarya, 54200, Turkey \\ IIDepartment of Molecular Biology and Genetics, Biotechnology, Faculty of Science, Bartin University, Bartin, 74100, Turkey \\ TLaboratory of Diagnostics and Analysis, Faculty of Veterinary Medicine, Afyon Kocatepe University, Afyon, 03200, Turkey
}

\begin{abstract}
The isolation and identification of microorganisms associated with digital dermatitis (DD) in Turkish dairy cattle was investigated using punch skin biopsy samples from typical clinical lesions; they were collected from dairy farms and abattoirs in 5 different geographical locations in Turkey. Morphological characteristics and flagellation types were examined using a transmission electron microscope, and their enzyme profiles by enzyme activation kits; their catalase reaction characteristics were evaluated by the addition of $3 \% \mathrm{H}_{2} \mathrm{O}_{2}$. Their phylogenies were identified using $16 \mathrm{~S}$ rRNA and the results compared with known gene bank data. Bacterial cells were 5.0 to $18.2 \mu \mathrm{m}$ long, 0.2 to $0.5 \mu \mathrm{m}$ wide, and their minimum number of periplasmic flagellum was $4(4: 8: 4)$ with a maximum of 8 (8:16:8). All isolates were catalase negative. Of the spirochetes isolated and identified, group I organisms showed close similarity with Treponema pedis (99\% genetic homology), whereas those in group II were similar to Treponema phagedenis (98\% homology). This is the first report of specific sub-groups of Treponema spp., isolated from Turkish dairy cattle presenting with DD lesions, being associated with this disease; these morphotypes were similar to those found globally in housed dairy cattle units and are probably significant microorganisms associated with the aetiopathogensis of this infectious disease causing acute bovine lameness. These results suggest that the distribution of DD-associated treponemes is not specific to particular geographic regions of Turkey.
\end{abstract}

Received December 1, 2017.

Accepted July 20, 2018.

${ }^{1}$ Corresponding author: idemirkan@aku.edu.tr
Key words: treponeme, bovine dermatitis digitalis, isolation, identification

\section{INTRODUCTION}

Lameness in cattle, housed in intensively farmed dairy units, is the third most important negative factor affecting herd health and production; following digestive disorders and mastitis/low infertility (Russell et al., 1982; Green et al., 2002; Ettema et al., 2010). The US National Animal Health Monitoring System stated that digital dermatitis (DD) is the second most common health concern in dairy cattle (USDA, 2009). Digital dermatitis was first reported in Italy by Cheli and Mortellaro (1974) and described subsequently in many countries worldwide (Laven, 2001; Demirkan and Güzel, 2004; Holzhauer et al., 2006; Cartwright, et al., 2017; Ekman, et al., 2018). This disease causes significant financial loss and lowered welfare in affected cattle (Winckler and Willen, 2001); the severe pain caused by lesions is sufficient to reduce milk yield (Nielsen et al., 2012), estimated at around $\$ 190 \pm 30$ million annually in the US dairy industry (Losinger, 2006). A more recent estimate by Charfeddine and Pérez-Cabal (2017) puts the annual cost per cow at $\$ 10.80$ in an average affected milking herd of 64 cows. Jacobs et al. (2017) described an outbreak of DD in yearling dairy replacements that may be associated with an increased prevalence of DD in the same lactating herd.

Histopathological examination of DD lesion biopsies have shown consistently that spirochete-like microorganisms are present (Demirkan et al., 1999; Santos et al., 2012), and these are now known to be treponemes that appear phylogenetically and serologically diverse within lesions and in different countries (Schrank et al., 1999; Stamm et al., 2002; Elliott et al., 2007; Evans et 
al., 2009b; Yano et al., 2010; Wilson-Welder et al., 2013; Gomez et al., 2014; Nascimento et al., 2015). These treponemes are clustered within 3 groups, described as Treponema medium/Treponema vincentii-like, Treponema phagedenis-like, and Treponema denticola/Treponema putidum-like (Evans et al., 2008), the latter now classified as a new species, Treponema pedis (Evans et al., 2009a).

The aetiopathogenesis of DD has been investigated extensively. It is now accepted that Treponema microorganisms are the predominant morphotypes cultured from active digital lesions (Walker et al., 1995; Murray et al., 2002; Nielsen et al., 2016).

The fastidious and fragile nature of all treponemes associated with DD lesions make their isolation and culture very difficult, but this can be facilitated by using specific culture conditions under a strict anaerobic atmosphere. The objective of this study was to describe characteristics of treponemes isolated from DD lesions and their presence in Turkish dairy cattle.

\section{MATERIALS AND METHODS}

Practicing veterinary surgeons responsible for the health and welfare of large dairy units in 5 different geographical locations of Turkey were recruited in a nationwide study to investigate clinical cases of DD in lame dairy cows, using punch biopsy samples: normal healthy digital skin biopsies were taken from the palmar aspect of the hind limb interdigital space in dairy cattle at abattoirs immediately after slaughter, in the same regions. Before the study began, all participating veterinary surgeons viewed a video film that described typical lesions, the correct method for obtaining biopsy samples from them, and their cleaning, handling, and labeling.

The research protocol was approved by the Institutional Animal Use and Ethical Committee of Afyon Kocatepe University, Turkey.

\section{Biopsy Sampling and Handling}

After examining clinically lame cattle $(\mathrm{n}=52$; Simmental cows between first and fourth lactation periods with an average of 6,000 L/lactation milk yield, mean herd size of 200, and housed with a common lying area with cubicles), presenting with lesions typical of DD in either front or hind feet lesions were scored by clinicians according to the Iowa system: 0 denoted normal healthy skin; A1 denoted a nonproliferative dermatitis with or without dermal pitting in the interdigital fold; A2 denoted advanced erosion and proliferation within the interdigital fold; B1 denoted focal or multifocal proliferative scabs on heel skin; B2 denoted diffuse proliferative scabs across the heel; 3 denoted focal area of hyperaemic ulceration within the areas described in A2 or B2; 4 denoted chronic papillomatous lesions (Krull et al., 2014). Lesions were then washed and cleaned using sterile PBS ( $\mathrm{pH}$ 7.4) before local analgesia (ring block; $2 \%$ lidocaine; Adeka, Istanbul, Turkey). After 5 min, $6 \mathrm{~mm}$ diameter skin punch biopsies were obtained and washed again in PBS: care was taken to ensure that the skin sample was full thickness and included both epidermis and dermis. The washed biopsy was placed in $2 \mathrm{~mL}$ of Oral Treponeme Enrichment Broth (OTEB; Anaerobe Systems, Morgan Hill, CA), supplemented with $5 \mathrm{mg} / \mathrm{L}$ of rifampicin (Panreac, AppliChem, Darmstadt, Germany) and $5 \mathrm{mg} / \mathrm{L}$ of enrofloxacin (Santa Cruz Biotechnology, Santa Cruz, CA) in a 20$\mathrm{mL}$ sterile plastic container, and labeled: normal skin samples obtained from abattoirs $(\mathrm{n}=20)$ were handled in the same way. Samples were sent to the laboratory where the biopsies were placed in an anaerobic cabinet with at an atmosphere of $85 \% \mathrm{~N}_{2}, 10 \% \mathrm{H}_{2}$, and $5 \% \mathrm{CO}_{2}$ (Don Whitley Scientific, Bingley, UK) at $36^{\circ} \mathrm{C}$ and $45 \%$ relative humidity.

All subsequent procedures was carried out in the anaerobic cabinet. Biopsies were divided into 2 portions: the first portion was used for the spirochete isolation and the second portion for histopathological examination.

\section{Spirochete Isolation}

The biopsy portion was diced and placed in fresh OTEB supplemented with $10 \%$ fetal calf serum (Biochrom, Berlin, Germany) and $5 \mathrm{mg} / \mathrm{L}$ of rifampicin (Panreac, AppliChem, Germany) and $5 \mathrm{mg} / \mathrm{L}$ enrofloxacin (Santa Cruz Biotechnology) for $48 \mathrm{~h}$. A drop of the OTEB was then subcultured on fastidious anaerobe agar (FAA; Acumedia-Neogen, Lansing, MI) supplemented with 5\% defibrinated sheep blood (Pendik Veteriner Arastirma Enstitisu, Istanbul, Turkey), 10\% fetal calf serum, and $5 \mathrm{mg} / \mathrm{L}$ of rifampicin and $5 \mathrm{mg} / \mathrm{L}$ of enrofloxacin for up to $2 \mathrm{wk}$. Then, several of the resulting colonies were inoculated into OTEB without antibiotics and stored in beads-rings storage tubes (Protect; Thermo Fisher Scientific, Waltham, MA) at $-80^{\circ} \mathrm{C}$.

\section{DNA Extraction}

The GeneJET Genomic DNA purification kit (Thermo Fisher Scientific, Waltham, MA) was used to 
extract DNA from all biopsies and the DNA was stored at $-20^{\circ} \mathrm{C}$ until analyzed.

\section{DNA Extraction from Culture}

The DNA was extracted from treponeme cultures as described by Demirkan et al. (2001). Briefly, the 7-dold OTEB cultures were centrifuged at 12,000 $\times g$ for 20 min at $4^{\circ} \mathrm{C}$, and DNA was isolated from the resulting pellet using a commercially available extraction kit (Thermo GeneJET Genomic DNA Purification kit, Thermo Fisher Scientific).

\section{PCR Amplification}

The forward primer (5'-AGA GTT TGA TCC TGG CTC AG-3') and the reverse primer (5'-AAG GAG GTG ATC CAG CCG CA-3') were used to amplify $16 \mathrm{~S}$ rRNA gene analysis previously studied by Demirkan et al. (2001). Briefly, the 25- $\mu \mathrm{L}$ PCR mixture consisted of $2 \mu \mathrm{L}$ of DNA $(30-40 \mathrm{ng} / \mu \mathrm{L}), 0.5 \mu \mathrm{L}$ of each primer containing 10 pmol, $1 \mu \mathrm{L}$ of $\mathrm{MgCl}_{2}$ at $50 \mathrm{mM}, 2.5 \mu \mathrm{L}$ of 10 $\times$ PCR buffer, $0.5 \mu \mathrm{L}$ of deoxynucleotide triphosphate mix, $0.1 \mu \mathrm{L}$ of Platinium Taq DNA Polymerase (Invitrogen, Carlsbad, CA), and $17.9 \mu \mathrm{L}$ of double-distilled $\mathrm{H}_{2} \mathrm{O}$. The reaction was carried out for 2 min at $94^{\circ} \mathrm{C}$ (pre-denaturation), $45 \mathrm{~s}$ at $94^{\circ} \mathrm{C}$ (denaturation), $30 \mathrm{~s}$ at $57^{\circ} \mathrm{C}$ (annealing), and $1 \mathrm{~min}$ at $72^{\circ} \mathrm{C}$ (extension) for 35 complete cycle: the last extension was at $72^{\circ} \mathrm{C}$ for $10 \mathrm{~min}$.

\section{DNA Sequence Analysis}

A total of $5 \mu \mathrm{L}$ of PCR product was cleaned with Exonuclease I $0.5 \mu \mathrm{L}$ (EN0582; Thermo, Vilnius, Lithuania) and FastAP Thermosensitive Alkaline Phosphatase 1 $\mu \mathrm{L}$ (EF0651; Thermo). The DNA sequence analysis was run in a total of a $20-\mu \mathrm{L}$ mixture consisting of $1 \mu \mathrm{L}$ of Big Dye 3.1, $13.5 \mu \mathrm{L}$ of $1 \times$ sequencing buffer, $5 \mu \mathrm{L}$ of each primer ( $1 \mathrm{pmol})$, and $1 \mu \mathrm{L}$ of PCR product. The $\mathrm{PCR}$ reaction was set at $2 \mathrm{~min}$ at $96^{\circ} \mathrm{C}$ (pre-denaturation), $96^{\circ} \mathrm{C}$ for $10 \mathrm{~s}$ (denaturation), $50^{\circ} \mathrm{C}$ for $15 \mathrm{~s}$ (annealing), and $60^{\circ} \mathrm{C}$ for 4 min (extension) for 30 cycles. The amplicons were purified using BigDye XTerminator purification kit (4376487; Thermo). Then the amplicons were subjected to nucleotide sequencing [Sequencher 5.4.6 (Gene Codes Corporation, Ann Arbor, MI)]. The sequence was edited by MEGA4 (Tamura et al., 2007) and BioEdit 7.0.9 Sequence Alignment (Hall 1999) and compared with GenBank with accession numbers of MG545730 (Treponema AKS7.TOVAG112O888), MG545731 (Treponema BAL2.TOVAG112O888), and MG545729 (BUR4.TOVAG112O888). A phylogenetic tree was constructed.

\section{Histology}

Biopsies were fixed routinely in $10 \%$ formalin and embedded in paraffin wax. Sections $5 \mu \mathrm{m}$ thick were stained: hematoxylin-eosin stain was used to identify histopathological changes and Warthin-Starry stain to visualize spirochetes present, all under light microscopy.

\section{Electron Microscopy}

Bacterial morphology was investigated using transmission electron microscopy. A drop of 7-d-old OTEB cultures was placed on a formvar grid. After washing 3 times with distilled water, the grid was dried with filter paper, negatively stained with $2 \%$ phosphotungstic acid (Sigma Aldrich, Interlab AS, Istanbul, Turkey) at pH 7 for 1 min, then air-dried and examined.

\section{Enzyme Activity}

Seven-day-old OTEB cultures were centrifuged at $12,000 \times g$ for $20 \mathrm{~min}$ at $4^{\circ} \mathrm{C}$. After removal of the supernatant, the remaining pellet was washed twice with PBS (pH 7.2) and its density adjusted at 5 MacFarland turbidity. Analysis for the presence of C14 lipase, valine arylamidase, cystine arylamidase, $\alpha$-galactosidase, $\alpha$-mannosidase, and $\alpha$-fucosidase was carried out according to the API-ZYM manufacturer's instructions (www.biomerieux.com.tr; bioMérieux, Istanbul, Turkey). For catylase estimation, a drop of $\mathrm{H}_{2} \mathrm{O}_{2}(3 \%)$ was placed on the pellet and bubble formation was considered a positive catalase reaction.

\section{RESULTS}

From large dairy farms in 5 regions of Turkey, 52 lame Simmental cows presenting lesions typical of DD were examined by a veterinary surgeon and biopsies were taken according to the protocol described earlier (Table 1). The most common lesion presented was Iowa score $4(\mathrm{n}=22)$, followed by scores $3(\mathrm{n}=18)$, A1 $(\mathrm{n}=5), \mathrm{A} 2(\mathrm{n}=4)$, and B2 $(\mathrm{n}=3)$, located in the palmar aspect of the interdigital space midway between the both heel bulbs; in chronic cases they extended upward and horizontally to affect adjacent hairy skin. Lesions were prone to bleeding when they were cleaned, and very sensitive when touched. Untreated chronic lesions often presented with matted hairs surrounded the wound edge, and epidermal spikes protruded from the surface of the lesion; pain was less pronounced. Biopsy samples reached the laboratory where further tissue processing took place varied between 1 and $3 \mathrm{~d}$ depending on the courier service. 
Table 1. The number of biopsy samples submitted for investigation by veterinary surgeons, their geographical region of origin, and the microorganisms cultured and identified by DNA sequence analysis

\begin{tabular}{|c|c|c|c|c|c|c|}
\hline \multirow[b]{2}{*}{ Origin of biopsies and culture outcomes } & \multicolumn{5}{|c|}{ Region } & \multirow[b]{2}{*}{ Total } \\
\hline & Agean & Marmara & Central & Black Sea & South-east & \\
\hline \multicolumn{7}{|l|}{ Treponemes cultured: } \\
\hline Treponema pedis-like & 5 & 4 & 9 & 4 & 3 & 25 \\
\hline Treponema phagedenis-like & 3 & 5 & 2 & 4 & 1 & 15 \\
\hline \multicolumn{7}{|l|}{ Other anaerobes cultured: } \\
\hline Desulfovibrio desulficans & 4 & 6 & 0 & 5 & 4 & 19 \\
\hline
\end{tabular}

\section{Histopathology}

Microscopic examination of stained sections revealed subcorneal pustulous developments (Iowa score A1, $\mathrm{n}=$ 5 ), and in some cases, continuity of epidermal mucosa had partially (erosion) or completely (ulcer) disappeared. Necrotic tissues with hyperemic vessels were also observed in the region (ulcer and hyperemia; Iowa scores $\mathrm{A} 2, \mathrm{n}=4 ; \mathrm{B} 2, \mathrm{n}=3$; and $3, \mathrm{n}=18$ ). Typical hyperkeratosis of the outermost epidermal layer, and spirochetes colonies were located sporadically among the disrupted keratin throughout the epidermis. Extensive acanthosis was observed in the stratum spinosum together with cellular degeneration (Iowa score 4, $\mathrm{n}=22$ ); in some fields, changes varied from hydropic degeneration to ballooning degeneration. Basal cell hyperplasia was common and some cells were undergoing mitosis. In the dermis, the cellular inflammatory response was predominantly a neutrophilic infiltration.
On the examination of Warthin-Starry, stained sections were detected in long spiral-shaped bacteria form of single or bundle on superficial and deeper in the hyperkeratotic epidermal layer (Figure 1).

\section{Treponeme Culture, Identification, Morphological, and Enzyme Characteristics}

Healthy skin biopsies $(\mathrm{n}=20)$ obtained from slaughterhouse material failed to produce any treponeme microorganism, whereas treponemes were cultured successfully from $40(77 \%)$ lesions out of 52 ; all isolates had similar characteristic growth patterns in OTEB. Within $48 \mathrm{~h}$, treponeme growth was visible as cottonlike strands toward the bottom of the culture tubes that grew into translucent, hazy, circumscribed colonies, $0.4-0.6 \mathrm{~mm}$ in diameter, in FAA after about $7 \mathrm{~d}$. After $2 \mathrm{wk}$, the colonies were approximately $2.5 \mathrm{~mm}$ in diameter and had penetrated to a deeper layer of agar,

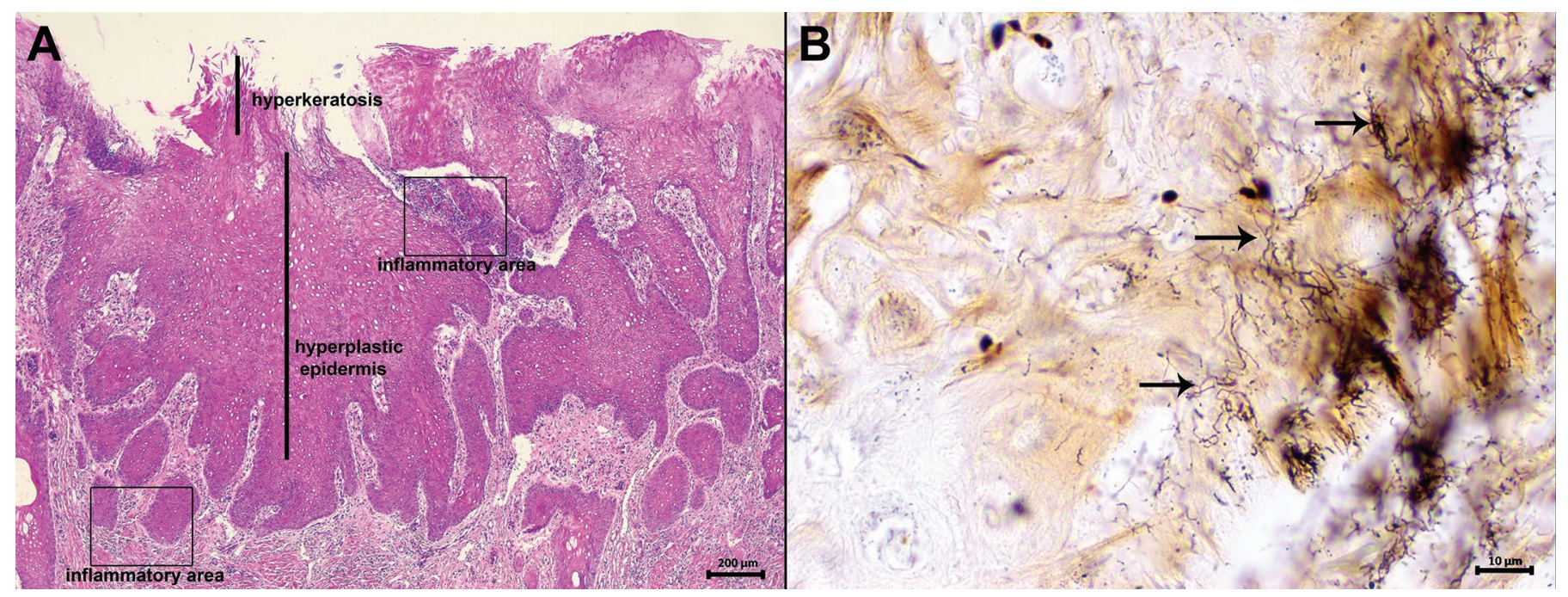

Figure 1. Histopathological appearance of digital dermatitis skin biopsy. (A) An inflammatory cell infiltrate is seen in the dermis with epidermal hyperplasia and hyperkeratosis. Hematoxylin-eosin staining. Bar: actual length $=200 \mu$ m. (B) Digital dermatitis skin biopsy stained with Whartin-Starry method: long spiral-shaped bacteria/spirochetes (arrows). Bar: actual length $=10 \mu \mathrm{m}$. Color version available online. 
Table 2. Bacterial size and flagella number of treponemes identified in this study, compared with Treponema pedis and Treponema phagedenis characteristics described by Evans et al. (2008) and Wilson-Welder et al. (2013)

\begin{tabular}{|c|c|c|c|c|c|c|}
\hline \multirow[b]{2}{*}{ Treponeme and numbers examined (n) } & \multicolumn{2}{|c|}{ No. of flagella } & \multicolumn{2}{|c|}{$\begin{array}{l}\text { Length } \\
(\mu \mathrm{m})\end{array}$} & \multicolumn{2}{|c|}{$\begin{array}{l}\text { Width } \\
(\mu \mathrm{m})\end{array}$} \\
\hline & Minimum & Maximum & Minimum & Maximum & Minimum & Maximum \\
\hline Group II T. phagedenis-like $(\mathrm{n}=18)$ & $6: 12: 6$ & $8: 16: 8$ & 7 & 12 & 0.3 & 0.5 \\
\hline Reference for T. pedis (Evans et al., 2008) & $3: 6: 3$ & $5: 10: 5$ & 5 & 16 & 0.2 & 0.3 \\
\hline Reference for T. phagedenis (Wilson-Welder et al., 2013) & $7: 14: 7$ & $9: 18: 9$ & 8 & 9.7 & 0.3 & 0.35 \\
\hline
\end{tabular}

displaying irregularly shaped $\beta$-hemolysis. No colonies grew in FAA without serum. Thereafter, when colonies were examined using dark field microscopy, large numbers of helically coiled bundles of slow-moving spirochetes were seen. They presented with snake-like, rotational movement in a lengthwise direction. Their individual cellular dimensions were 5.0 to $18.2 \mu \mathrm{m}$ long and 0.2 to $0.5 \mu \mathrm{m}$ wide. Flagella were present at both poles, overlapping midway along the body: the minimum number of periplasmic flagellum was 4 (4:8:4) and maximum 8 (8:16:8; Figures 2A and 2B; Table 2).

The $16 \mathrm{~S}$ rDNA analysis revealed that the spirochetes cultured were clustered within 2 main groups, similar to the phylogeny of Treponema phagedenis-like and $T$. pedis-like organisms (Figure 3). They were randomly distributed between the different lesion types (Table $3)$. The DNA sequence analysis showed that, apart from Treponema spp., Clostridium indolis $(\mathrm{n}=10)$, Clostridium sporosphaeroides $(\mathrm{n}=13$ ), or Desulfovibrio desulfuricans $(\mathrm{n}=19)$ were also identified in lesions.

Treponemes were clustered in 2 distinct groups for the pattern of enzyme reactivity; however, both groups were negative for C14 lipase, valine arylamidase, cystine arylamidase, $\alpha$-galactosidase, $\alpha$-mannosidase, and $\alpha$-fucosidase. However, both were positive for only $\mathrm{C} 4$ esterase, C8 esterase lipase, and leucine arlyamidase. Group II showed further reactivity to alkaline phophatase, acid phosphatase, naphtholphosphohydrolase, $\beta$-galactosidase, $\beta$-glucuronidase, and $N$-acetyl- $\beta$ glucosaminidase. Complete enzyme profiles are summarized in the species level in Table 4.

\section{DISCUSSION}

This paper describes, for the first time, the isolation and identification of treponemes associated with DD in dairy cattle in 5 geographically different regions of Turkey. The lesions themselves were similar to those described by others (Cheli and Mortellaro, 1974; Read and Walker, 1998; Murray et al., 2002; Berry et al., 2012), although the breeds of lame dairy cattle affected may have varied. Although Holstein or Friesian-
Holstein cows form the backbone of the dairy industry worldwide, managed usually in larger herds and housed partially or permanently throughout the year, Simmen-
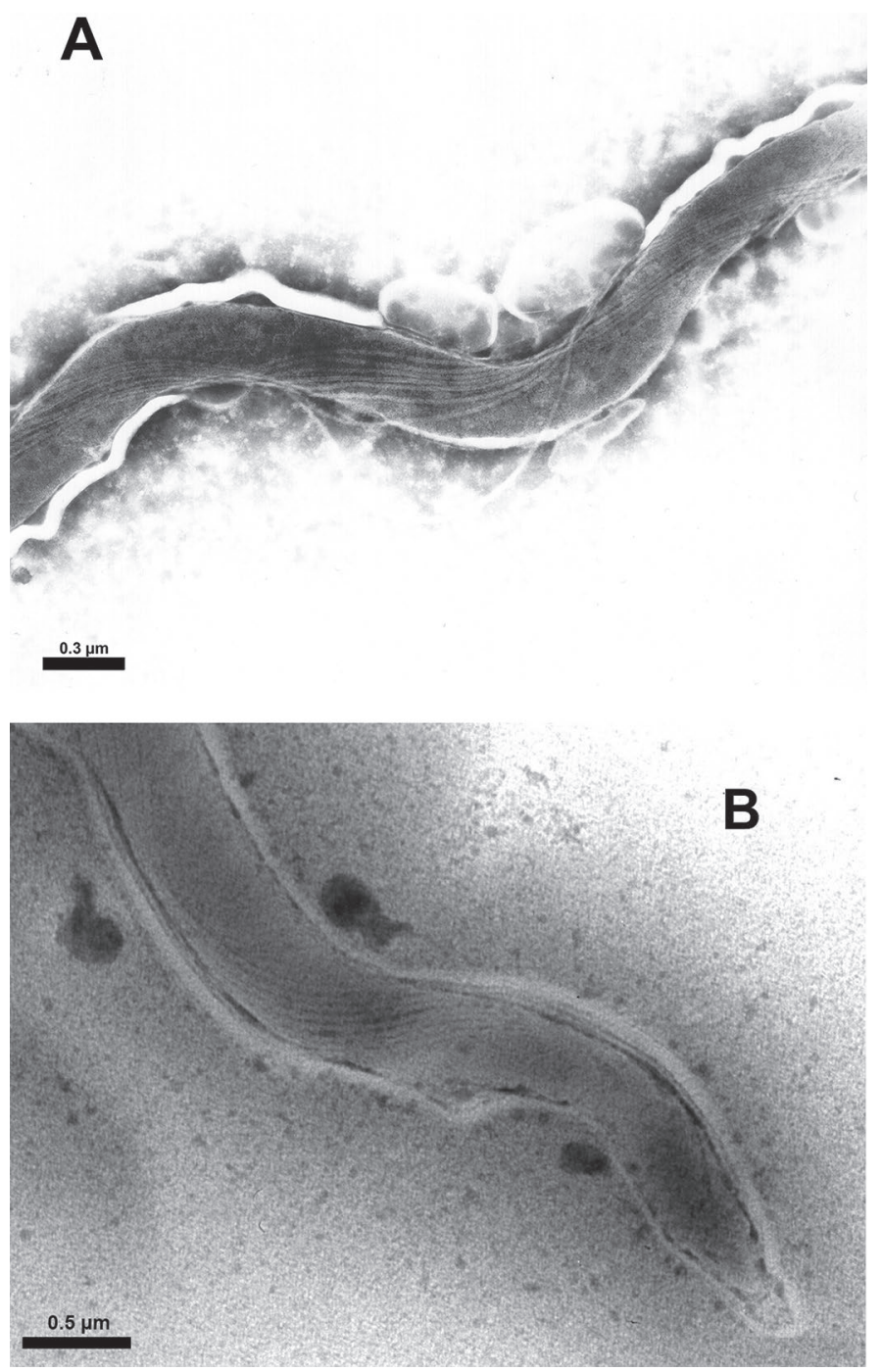

Figure 2. Electron micrographs of negatively stained spirochetes showing (A) 4:8:4 flagella pattern around midshaft of the cell (representing Treponema pedis-like isolate) and (B) 8:16:8 flagellation at one end of the cell (representing Treponema phagedenis-like isolate). 
Table 3. Distribution of treponemes in the lesion types

\begin{tabular}{lcccc}
\hline & Lesions & & \multicolumn{2}{c}{ No. of isolates cultured } \\
\cline { 1 - 2 } \cline { 5 - 5 } Iowa score & No. & & Treponema pedis-like & Treponema phagedenis-like \\
\hline A1 & 5 & 0 & 0 \\
A2 & 4 & & 2 & 4 \\
B2 & 3 & & 8 & 6 \\
3 & 18 & & 5 & 4 \\
4 & 22 & & 25 & 15 \\
Total & 52 & & & 4 \\
\hline
\end{tabular}

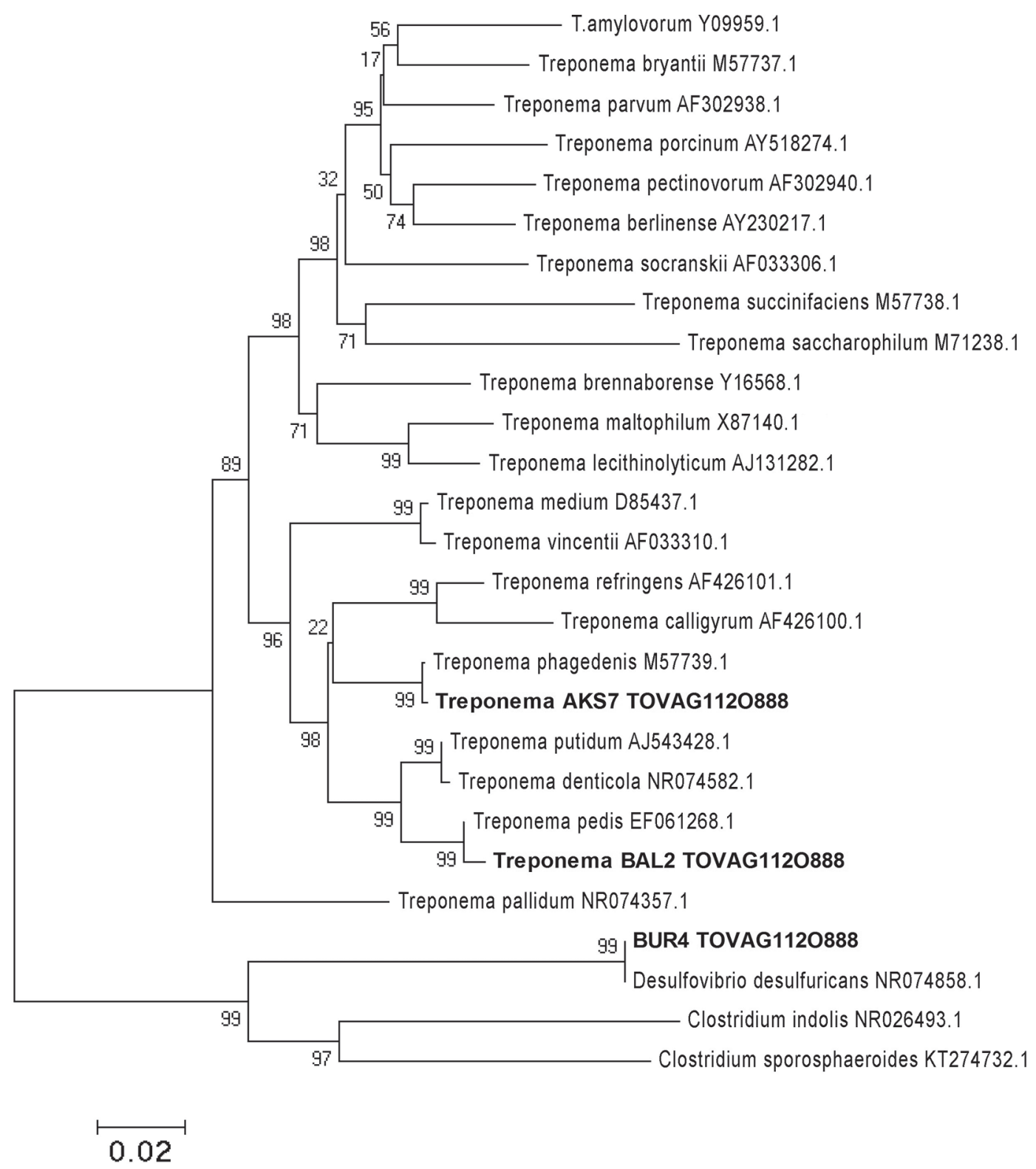

Figure 3. Neighbor-joining phylogenetic tree with respect to $16 \mathrm{~S}$ rRNA gene sequence comparisons of $\sim 1,400$ aligned bases (TOVAG112O888 in this study). 
tal cattle were the predominant breed in this present study. This suggests that risk factors for this disease reside both within the normal anatomical features of the bovine digit, irrespective of breed, and the external conditions that surround it.

The DD skin samples were taken during routine farm visits and the farm personnel selected lame cows for DD biopsy sampling in this study. This purposive sampling method may be biased (Cramer et al., 2018). The early stages causing no lameness can be easily missed or ignored by farm workers. Thus, to identify or score DD with no lameness, cows should be placed in a trimming chute or observed in the milking parlor by washing or cleaning the feet before close examination under proper lighting. Thus, the stages in this study, were predominantly stages 3 and 4 . Moreover, these stages matched the previous descriptions, developed by Döpfer et al. (1997) and amended by Berry et al. (2012), relatively well (i.e., M2 and M4 classes).

Treponemes in this study could be clearly distinguished by their cell size and flagellation types from other DD-associated treponema isolates. The cells of Treponema brennaborense (German isolate; Schrank et al. 1999) were 5 to $8 \mu \mathrm{m}$ long and 0.25 to $0.55 \mu \mathrm{m}$ wide with a cytoplasmic cylinder surrounded by 2 periplasmic flagella that originated subterminally at each pole, T. pedis (UK isolate; Evans et al., 2009a) were 5 to 16 $\mu \mathrm{m}$ long and 0.2 to $0.3 \mu \mathrm{m}$ wide with 6 periplasmic flagella (3 originating at each end and overlapping in the central region of the cell), and US isolates (Walker et al., 1995) were 0.23 to $0.46 \mu \mathrm{m}$ wide and 5.5 to 13.5 $\mu \mathrm{m}$ length with flagella ranged from 5 to 9 at each terminus. However, our isolates, T. pedis-like and $T$. phagedenis-like, were 5.0 to $18.2 \mu \mathrm{m}$ long and 0.2 to 0.3 wide with 4 to 5 flagella, and 7 to $12 \mu \mathrm{m}$ long and 0.3 to $0.5 \mu \mathrm{m}$ wide with a pattern of 6 to 8 flagellation, respectively.

The enzyme pattern of reactivity of current isolates with positive results for esterase C4, esterase lipase C8, leucine arylamidase, trypsin, and chymotrypsin (group I isolates) was similar to UK bovine treponemes of group 3 and $T$. pedis except for leucine arylamidase (Evans et al., 2008 and 2009a, respectively). Group II isolates shared similar reactivity with $T$. phagedenis Kazan except for $\beta$-galactosidase (Wilson-Welder et al., 2013). The enzyme profiles of the current isolates produced a specific pattern that differed from the genus Treponema shown in Table 4.

The 16S rDNA sequencing of the spirochetes cultured and isolated in this present study were of the genus Treponema and were related to those found in either the T. pedis-like or T. phagedenis-like sub-groups. Evans et al. (2009b) suggested that this disease was polytreponemal involving the sub-groups T. pedis-like, T. phagedenis-like, and T. medium-like: now we know that T. denticola (Choi et al., 1997) and 1-9185MED (Walker et al., 1995) are within the T. pedis-like subgroup, and simplifies what appears to be a confusing

Table 4. Enzyme activities of bovine and other treponeme strains as determined by the API-ZYM system (bioMérieux, Istanbul, Turkey) ${ }^{1}$

\begin{tabular}{|c|c|c|c|c|c|c|c|c|c|c|c|c|c|c|c|c|c|c|c|}
\hline Species $^{2}$ & \multicolumn{19}{|c|}{ Enzyme activity $^{3}$} \\
\hline This study, group II $(\times 18)$ & + & + & + & - & + & - & - & - & - & + & + & - & + & + & - & - & + & - & - \\
\hline Treponema pedis ${ }^{\mathrm{E} 1}$ & - & + & + & - & - & - & - & + & + & - & - & - & - & - & - & - & - & - & - \\
\hline Treponema phagedenis Kazan ${ }^{{ }_{w}}$ & + & + & + & - & + & - & - & - & - & + & + & - & + & - & - & - & + & - & - \\
\hline T. phagedenis Reiter ${ }^{\mathrm{S}}$ & - & - & - & - & - & - & - & - & - & + & - & - & + & + & - & - & + & - & - \\
\hline Treponema medium (ATCC $\left.700293^{\mathrm{T}}\right)^{\mathrm{S}}$ & + & + & + & - & + & - & - & - & - & - & - & - & + & - & - & - & - & - & - \\
\hline Treponema vincenti (ATCC 35580$)^{\mathrm{S}}$ & - & - & - & - & + & - & - & - & - & + & + & - & + & - & - & - & + & - & - \\
\hline Treponema denticola (ATCC $\left.35405^{\mathrm{T}}\right)^{\mathrm{Wl}}$ & - & + & - & - & - & - & - & + & + & - & - & - & - & - & - & - & - & - & - \\
\hline T. denticola (ATCC 35405) ${ }^{\mathrm{Ww}}$ & - & + & + & - & - & - & - & + & - & + & + & + & - & - & + & - & - & - & - \\
\hline Treponema putidum (ATCC $\left.700334^{\mathrm{T}}\right)^{\mathrm{Wy}}$ & + & + & + & - & + & - & - & + & + & + & + & + & + & - & + & + & - & - & - \\
\hline UK bovine treponemes, group $1(\times 5)^{\mathrm{E} 2}$ & + & + & + & - & + & - & - & - & - & + & - & - & - & - & - & - & - & - & - \\
\hline UK bovine treponemes, group $2(\times 14)^{\mathrm{E} 2}$ & + & + & + & - & - & - & - & - & - & + & + & - & + & + & - & - & + & - & + \\
\hline
\end{tabular}

${ }^{1}$ All treponeme strains given in the table generated negative results for C14 lipase, valine arylamidase, cystine arylamidase, and $\alpha$-fucosidase.

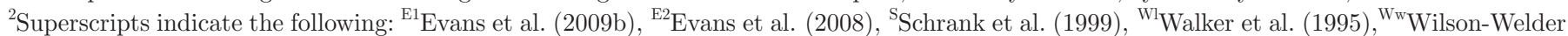
et al. (2013), ${ }^{\mathrm{Wy}}$ Wyss et al. (2004).

${ }^{3}$ Enzymes: 1, alkaline phosphatase; 2, C4 esterase; 3, C8 esterase lipase; 4, C14 lipase; 5, leucine arylamidase; 6, valine arylamidase; 7, cystine arylamidase; 8 , trypsin; 9, chymotrypsin; 10, acid phosphatase; 11, naphtholphosphohydrolase; 12 , $\alpha$-galactosidase; 13 , $\beta$-galactosidase; 14 , $\beta$-glucuronidase; 15, $\alpha$-glucosidase; 16, $\beta$-glucosidase; 17, $N$-acetyl- $\beta$-glucosaminidase; 18, $\alpha$-mannosidase; 19, $\alpha$-fucosidase. 
microbiological component of the aetiopathogenesis of this disease. Treponemes appear to be the major taxonomic unit associated with DD.

Despite the geographical and climatic diversity of the dairy farms studied in these 5 regions of Turkey (e.g., the eastern part is mountainous with nighttime temperatures dropping below $-30^{\circ} \mathrm{C}$ and altitudes of some farms are around 1,000 $\mathrm{m}$ above sea level, whereas western and southern areas have a temperate climate), highly similar treponeme bacteria were isolated.

It is accepted that treponemes are the primary infectious microorganisms associated with DD but an increasing number of other morphotypes, mostly anaerobes, have been isolated from active lesions. One of the first identified was Campylobacter faecalis (Döpfer et al., 1997) with other research groups assigning Peptococcus asaccharolyticus, Pc. saccharolyticus, Peptostreptococcus anaerobius, Bacteroides asaccharolyticus, B. melaninogenicus, Fusobacterium spp., Streptococcus, and Clostridium spp. to the list (Koniarová et al., 1993; Santos et al., 2012). In this study, Clostridium indolis, C. sporosphaeroides, and D. desulfuricans were identified; the latter, a sulfate-reducing, motile, gram-negative, anaerobic bacterium can be found in the gastrointestinal tract (Beerens and Romond, 1977) and has been implicated in human ulcerative colitis (Gibson et al., 1988). Aforementioned studies indicate that this bacterium originates from environmental contamination because it appears to be ubiquitous in the environment. Therefore, during sampling of DD lesions to remove environmental sources such as $D$. desulfuricans, the entire removal of the surface debris by vigorous washing should be considered. All 3 organisms have been found in mud, brackish water, sewage, and industrial and freshwater sediments (Johnson and Finegold, 1987) and the Clostridia spp. are present in the gastrointestinal tracts of sheep, dogs, pigs, hamsters, and ferrets (Fox et al., 1994; Shukla and Reed, 2000). Although it is possible that these organisms were contaminants and present in lesions because of their incorrect washing and cleaning before biopsy, the presence of Clostridia spp. may be significant.

Previously, infectious diseases were often considered to be mono-microbial but this perception of DD is being challenged frequently of late. The diverse bacterial microbiome described in DD lesions may be more significant during the early stages of lesion development (Krull et al., 2014) as is the case with other treponemeassociated diseases such as gingivitis in the human oral cavity (Edwards et al., 2003). We observed that treponemes were absent in the early stages of the lesion (Iowa score A1); however, they were more abundant in the advanced stages (Iowa scores 3 and 4). Treponema isolation success rate was $77 \%$ in this study. This does not rule out the existence of other noncultivable species of Treponema spp. in DD in Turkish dairy cattle. Above all, determination of the temporal microbiota changes by deep sequencing-based metagenomic evaluation of DD biopsy specimens by Krull et al. (2014) suggests that early detection of treponemes in DD may be unrewarding because the amount of treponeme DNA obtained from different stages of DD increased as the lesion scores increased. This may explain why isolation attempts failed in the early stages as in our study and this may also raise a question whether treponemes are the initiating organisms in the first place or late arrivals on the scene of already disrupted bovine hoof skin.

The attachment of one bacterial species to a hosts' tissues, through micro-trauma of skin epidermis (Read and Walker, 1998) or mucosal surfaces (Edwards et al., 2003), may allow polymicrobial biofilm organisms to invade that site: the initial attachment of one bacterial species providing the scaffold for other species to adhere to. As a result, the initial colonizers determine which microbes are isolated from lesions at a later time: this process is known as coaggregation, which may be mediated in 2 ways. First, the opportunistic secondary organism binds to specific molecules on the surface of a biofilm; or second, several bacteria combine to form an aggregate that provokes phenotypic change, leading to further coaggregation on the outside of the biofilm, which extends the biofilm matrix into the extracellular environment of the host. In this way, competing microbes may increase the colonization surface area and position themselves nearer to potential sources of nutrition. This concept is illustrated well in Figure 1, where pathogens were present deep within the disrupted keratin throughout the epidermis, and acanthosis and cellular degeneration was extensive in the stratum spinosum. Clostridium indolis secretes histotoxins that characterize ulcerative colitis lesions in animals and humans (Berger, 2015) and the variety of secondary microorganisms found in DD lesions may well account for some of their differing clinical presentations.

\section{CONCLUSIONS}

This is the first report on isolation of treponemes from dairy cattle suffering from DD in Turkey. Our work indicated that the spirochetes found in bovine DD were most closely related to T. pedis and T. phagedenis. Deeper sequencing or more extensive culturing is needed to determine the entire microbial profile and to identify the role(s) of these isolates in different stages of lesions to develop effective prevention strategies, putting the pathogen(s) on the central stage. Ultimately, efforts should be focused on improving the underfoot environment and hygiene of dairy cattle in 
particular, and developing a polymorphic treponeme vaccine.

\section{ACKNOWLEDGMENTS}

A part of this study was presented at the 32nd World Veterinary Congress as a poster (September 13-17, 2015, Istanbul, Turkey). The authors gratefully acknowledge the financial support of the Scientific and Technological Council of Turkey (TUBITAK-TOVAG 1120888) for this project. We thank R. D. Murray of Liverpool, United Kingdom, for his valuable critique and language editing of the manuscript. We also thank D. Temizsoylu of Mehmet Akif University, Burdur, Turkey; F. Alkan of Selçuk University, Konya, Turkey; G. Çeçen of Uludağ University, Bursa, Turkey; and A. Hayat of Harran University, Urfa, Turkey, for providing DD biopsy samples from different geographic locations of Turkey and I. Dağ of Osman Gazi University, Eskişehir, Turkey, for the transmission electron microscopy analysis.

\section{REFERENCES}

Beerens, H., and C. Romond. 1977. Sulfate-reducing anaerobic bacteria in human feces. Am. J. Clin. Nutr. 30:1770-1776.

Berger, S. 2015. Clostridium indolis. Page 525 in GIDEON Guide to Medically Important Bacteria, Gideon Informatics, Los Angeles, CA.

Berry, S. L., D. H. Read, T. R. Famula, A. Mongini, and D. Döpfer. 2012. Long-term observations on the dynamics of bovine digital dermatitis lesions on a California dairy after topical treatment with lincomycin $\mathrm{HCl}$. Vet. J. 193:654-658. https://doi.org/10 $.1016 / j . t v j 1.2012 .06 .048$.

Cartwright, S. L., F. Malchiodi, K. Thompson-Crispi, F. Miglior, and B. A. Mallard. 2017. Prevalence of digital dermatitis in Canadian dairy cattle classified as high, average, or low antibody- and cellmediated immune responders. J. Dairy Sci. 100:8409-8413. https: //doi.org/10.3168/jds.2016-12157.

Charfeddine, N., and M. A. Pérez-Cabal. 2017. Effect of claw disorders on milk production, fertility, and longevity, and their economic impact in Spanish Holstein cows. J. Dairy Sci. 100:653-665. https: //doi.org/10.3168/jds.2016-11434.

Cheli, R., and C. M. Mortellaro. 1974. Digital dermatitis in cattle. Pages 208-213 in the 8th International Meeting on Diseases of Cattle, Milan, Italy.

Choi, B. K., H. Nattermann, S. Grund, W. Haider, and U. B. Göbel. 1997. Spirochetes from digital dermatitis lesions in cattle are closely related to treponemes associated with human periodontitis. Int. J. Sys. Bacteriol. 47:175-181. https://doi.org/10.1099/ 00207713-47-1-175.

Cramer, G., T. Winders, L. Solano, and D. H. Kleinschmit. 2018. Evaluation of agreement among digital dermatitis scoring methods in the milking parlor, pen, and hoof trimming chute. J. Dairy Sci. 101:2406-2414. https://doi.org/10.3168/jds.2017-13755.

Demirkan, I., S. D. Carter, C. A. Hart, and J. M. Woodward. 1999 Isolation and cultivation of a spirochaete from bovine digital dermatitis. Vet. Rec. 145:497-498. https://doi.org/10.1136/vr.145.17 .497.

Demirkan, I., S. D. Carter, C. Winstanley, K. D. Bruce, J. M. McNair, M. Woodside, and C. A. Hart. 2001. Isolation and characterisation of a novel spirochaete from severe virulent ovine foot rot. J. Med.
Microbiol. 50:1061-1068. https://doi.org/10.1099/0022-1317-50-12 $-1061$.

Demirkan, I., and N. Güzel. 2004. An outbreak of digital dermatitis in Turkish dairy cattle. Indian Vet. J. 81:1331-1333.

Döpfer, D., A. A. H. M. ter Huurne, J. L. Cornelisse, A. J. A. M. van Asten, A. Koopmans, F. A. Meijer, Y. H. Schukken, I. Szakall, W. Klee, and R. B. Bosma. 1997. Histological and bacteriological evaluation of digital dermatitis in cattle, with special reference to spirochaetes and Campylobacter faecalis. Vet. Rec. 140:620-623. https://doi.org/10.1136/vr.140.24.620.

Edwards, A. M., D. Dymock, and H. F. Jenkinson. 2003. From tooth to hoof: Treponemes in tissue-destructive diseases. J. Appl. Microbiol. 94:767-780. https://doi.org/10.1046/j.1365-2672.2003.01901 .x.

Ekman, L., A. K. Nyman, H. Landin, U. Magnusson, and K. P. Waller. 2018. Mild and severe udder cleft dermatitis-Prevalence and risk factors in Swedish dairy herds. J. Dairy Sci. 101:556-571. https:// doi.org/10.3168/jds.2017-13133.

Elliott, M. K., D. P. Alt, and R. L. Zuerner. 2007. Lesion formation and antibody response induced by papillomatous digital dermatitis-associated spirochaetes in a murine abscess model. Infect. Immun. 75:4400-4408. https://doi.org/10.1128/IAI.00019-07.

Ettema, J., S. Østergaard, and A. R. Kristensen. 2010. Modelling the economic impact of three lameness causing diseases using herd and cow level evidence. Prev. Vet. Med. 95:64-73. https://doi.org/10 .1016/j.prevetmed.2010.03.001.

Evans, N. J., J. J. Brown, I. Demirkan, R. D. Murray, R. J. Birtles, C. A. Hart, and S. D. Carter. 2009a. Treponema pedis sp. nov., a novel spirochete isolated from bovine digital dermatitis lesions. Int. J. Syst. Evol. Microbiol. 59:987-991. https://doi.org/10.1099/ ijs.0.002287-0.

Evans, N. J., J. M. Brown, I. Demirkan, R. D. Murray, W. D. Vink, R. W. Blowey, C. A. Hart, and S. D. Carter. 2008. Three unique groups of spirochetes isolated from digital dermatitis lesions in UK cattle. Vet. Microbiol. 130:141-150. https://doi.org/10.1016/ j.vetmic. 2007.12.019.

Evans, N. J., J. M. Brown, I. Demirkan, P. Singh, B. Getty, D. Timofte, W. D. Vink, R. D. Murray, R. W. Blowey, R. J. Birtles, C. A. Hart, and S. D. Carter. 2009b. The association of unique, isolated treponemes with bovine digital dermatitis lesions. J. Clin. Microbiol. 47:689-696. https://doi.org/10.1128/JCM.01914-08.

Fox, J. G., F. E. Dewhirst, G. J. Fraser, B. J. Paster, B. Shames, and J. C. Murphy. 1994. Intracellular Campylobacter-like organism from ferrets and hamsters with proliferative bowel disease is a Desulfovibrio sp. J. Clin. Microbiol. 32:1229-1237.

Gibson, G. R., J. H. Cummings, and G. T. Macfarlane. 1988. Competition for hydrogen between sulphate-reducing bacteria and methanogenic bacteria from the human large intestine. J. Appl. Bacteriol. 65:241-247.

Gomez, A., K. S. Anklam, N. B. Cook, J. Rieman, K. A. Dunbar, K. E. Cooley, M. D. Socha, and D. Döpfer. 2014. Immune response against Treponema spp. and ELISA detection of digital dermatitis. J. Dairy Sci. 97:4864-4875. https://doi.org/10.3168/jds.2013 $-7616$.

Green, L. E., H. J. Hedges, Y. H. Schukken, R. W. Blowey, and A. J. Packington. 2002. The impact of clinical lameness on the milk yield of dairy cows. J. Dairy Sci. 85:2250-2256. https://doi.org/10 $.3168 /$ jds.S0022-0302(02)74304-X.

Hall, T. A. 1999. BioEdit: A user-friendly biological sequence alignment editor and analysis program for Windows 95/98/NT. Nucleic Acids Symp. Ser. 41:95-98.

Holzhauer, M., C. Hardenberg, C. J. M. Bartels, and K. Frankena. 2006. Herd-and cow-level prevalence of digital dermatitis in the Netherlands and associated risk factors. J. Dairy Sci. 89:580-588. https://doi.org/10.3168/jds.S0022-0302(06)72121-X.

Jacobs, C., K. Osrsel, and H. W. Berkema. 2017. Prevalence of digital dermatitis in young stock in Alberta, Canada, using pen walks. J. Dairy Sci. 100:9234-9244. https://doi.org/10.3168/jds.2017-13044.

Johnson, C. C., and S. M. Finegold. 1987. Uncommonly encountered, motile, anaerobic gram-negative bacilli associated with infection. Rev. Infect. Dis. 9:1150-1162. 
Koniarová,, I., A. Orsag, and V. Ledecký. 1993. The role anaerobes in dermatitis digitalis et interdigitalis in cattle. Vet. Med. (Praha) 38:589-596.

Krull, A. C., J. K. Shearer, P. J. Gorden, V. L. Cooper, G. J. Phillips, and P. J. Plummer. 2014. Deep sequencing analysis reveals the temporal microbiota changes associated with the development of bovine digital dermatitis. Infect. Immun. 82:3359-3373. https:// doi.org/10.1128/IAI.02077-14.

Laven, R. A. 2001. Control of digital dermatitis. In Practice 23:336341. https://doi.org/10.1136/inpract.23.6.336.

Losinger, W. C. 2006. Economic impacts of reduced milk production associated with papillomatous digital dermatitis in dairy cows in the USA. J. Dairy Res. 73:244-256. https://doi.org/10.1017/ S0022029906001798.

Murray, R. D., D. Y. Downham, I. Demirkan, and S. D. Carter. 2002. Some relationship between spirochaete infections and digital dermatitis in four UK dairy herds. Res. Vet. Sci. 73:223-230. https:/ /doi.org/10.1016/S0034-5288(02)00027-9.

Nascimento, L. V., M. T. Mauerwerk, C. L. Dos Santos, I. R. Barros Filho, E. H. Birgel Júnior, C. S. Sotomaior, H. M. Madeira, and R. D. Ollhoff. 2015. Treponemes detected in digital dermatitis lesions in Brazilian dairy cattle and possible host reservoirs of infection. J. Clin. Microbiol. 53:1935-1937. https://doi.org/10.1128/ JCM.03586-14.

Nielsen, B. H., P. T. Thomsen, L. E. Green, and J. Kaler. 2012. A study of the dynamics of digital dermatitis in 742 lactating dairy cows. Prev. Vet. Med. 104:44-52. https://doi.org/10.1016/j .prevetmed.2011.10.002.

Nielsen, M. W., M. L. Strube, A. Isbrand, W. D. H. M. Al-Medrasi, M. Boye, K. Tim, and J. K. Klitgaard. 2016. Potential bacterial core species associated with digital dermatitis in cattle herds identified by molecular profiling of interdigital skin samples. Vet. Microbiol. 186:139-149. https://doi.org/10.1016/j.vetmic.2016.03.003.

Read, D. H., and R. L. Walker. 1998. Experimental transmission of papillomatous digital dermatitis (footwarts) in dairy cattle. Page 270 in Proceedings of the 10th International Symposium on Lameness in Ruminants; Casino Lucerne, Switzerland. 7-10 September 1998

Russell, A. M., G. J. Rowlands, S. R. Shaw, and A. D. Weaver. 1982. Survey of lameness in British dairy cattle. Vet. Rec. 111:155-160. https://doi.org/10.1136/vr.111.8.155.

Santos, T. M., R. V. Pereira, L. S. Caixeta, C. L. Guard, and R. C. Bicalho. 2012. Microbial diversity in bovine papillomatous digital dermatitis in Holstein dairy cows from upstate New York. FEMS
Microbiol. Ecol. 79:518-529. https://doi.org/10.1111/j.1574-6941 2011.01234.x.

Schrank, K., B. K. Choi, S. Grund, A. Moter, K. Heuner, H. Nattermann, and U. B. Gobel. 1999. Treponema brennaborense sp. nov., a novel spirochaete isolated from a dairy cow suffering from digital dermatitis. Int. J. Syst. Bacteriol. 49:43-50. https://doi.org/10 .1099/00207713-49-1-43.

Shukla, S. K., and K. D. Reed. 2000. Desulfovibrio desulfuricans bacteremia in a dog. J. Clin. Microbiol. 38:1701-1702.

Stamm, L. V., H. L. Bergen, and R. L. Walker. 2002. Molecular typing of papillomatous digital dermatitis-associated Treponema isolates based on analysis of 16S-23S ribosomal DNA intergenic spacer regions. J. Clin. Microbiol. 40:3463-3469. https://doi.org/10.1128/ JCM.40.9.3463-3469.2002.

Tamura, K., J. Dudley, M. Nei, and S. Kumar. 2007. MEGA4: Molecular evolutionary genetics analysis (MEGA) software version 4.0 Mol. Biol. Evol. 24:1596-1599.

USDA. 2009. Dairy 2007, Part IV: Reference of dairy cattle health and management practices in the United States. USDA:APHIS: VS, CEAH, Fort Collins, CO.

Walker, R. L., D. H. Read, K. J. Loretz, and R. W. Nordhausen. 1995 Spirochetes isolated from dairy cattle with papillomatous digital dermatitis and interdigital dermatitis. Vet. Microbiol. 47:343-355.

Wilson-Welder, J. H., M. K. Elliott, R. L. Zuerner, D. O. Bayles, D. P. Alt, and T. B. Stanton. 2013. Biochemical and molecular characterization of Treponema phagedenis-like spirochetes isolated from a bovine digital dermatitis lesion. BMC Microbiol. 13:280. https:// doi.org/10.1186/1471-2180-13-280.

Winckler, C., and S. Willen. 2001. The reliability and repeatability of a lameness scoring system for use as an indicator of welfare in dairy cattle. Acta Agric. Scand. A Anim. Sci. 51(S30):103-107. https://doi.org/10.1080/090647001316923162.

Wyss, C., A. Moter, B. K. Choi, F. E. Dewhirst, Y. Xue, P. Schüpbach, U. B. Gobel, B. J. Paster, and B. Guggenheim. 2004. Treponema putidum sp. nov., a medium-sized proteolytic spirochaete isolated from lesions of human periodontitis and acute necrotizing ulcerative gingivitis. Int. J. Syst. Evol. Microbiol. 54:1117-1122. https://doi.org/10.1099/ijs.0.02806-0.

Yano, T., K. K. Moe, K. Yamazaki, T. Ooka, T. Hayashi, and N. Misawa. 2010. Identification of candidate pathogens of papillomatous digital dermatitis in dairy cattle from quantitative $16 \mathrm{~S}$ rRNA clonal analysis. Vet. Microbiol. 143:352-362. https://doi.org/10 $.1016 /$ j.vetmic.2009.12.009 